\title{
EMPLOYABILITY SKILLS: A SYSTEM OF RECOGNITION AT UNIVERSITAT JAUME I
}

\author{
María Isabel Beas-Collado ${ }^{1}$, Pilar García-Agustín ${ }^{2}$ \\ ${ }^{1}$ Head of Careers Service, Universitat Jaume I (SPAIN) \\ ${ }^{2}$ Vice-rector for Students, Employment and Educational Innovation, Universitat Jaume I
}

(SPAIN)

\begin{abstract}
Following CEDEFOP [1] the employability is "the combination of factors which enable individuals to progress towards or get into employment, to stay in employment and to progress during their career." Also, theories of employability have become increasingly complex and multi-dimensional in the last decades. [2]. Employability depends on the knowledge, skills and attitudes, how the graduate use those assets, and how the graduates present them to employers.

Moreover, there is an amount of work developed by Careers Services and faculties enhancing employabiity of our students through diferent initiatives and programmes (placements, workshops, career guidance, traning for job search, and so forth). Also University Jaume I has developed an educational model, in which their 10 principles we find "promotion of employability and the smart entrepreneurial spirit". However, from the vicerectorate for Students, Employment and Educational Innovation we want to go a step forward to enhance employability of our graduates launching a formal document that will be an edge in their curriculum.

The main aim of this system is to show a potential employer evidences of high impact employability soft and hard competences, achieved by graduates and undergraduates during their studies. This competences have been developed by the students through active participation in both extracurricular and curricular training, increasing of sensitivity and experience (skills acquired by practice) activities organised both by the University or other organisations, and recognised by an expert committee.
\end{abstract}

The aim of this communication is to explain the features of the system: background, requeriments for each activity, administrative procedure, and results.

Also we will comment on progress and future challenges of the system.

Keywords: Employability skills, recognition, University/Industry Experiences, Good practices.

\section{INTRODUCTION}

\subsection{Background}

Universitat Jaume I is the public university of Castelló. It was founded in 1991, nowadays it has +14000 degree and master students who are distributed in 77 formative profiles and 4 faculties. UJI has the EFQM 500+ hallmark and also UJI is among the top 500 universities in the world according to the Academic Ranking of World Universities (ARWU).

Since its inception, UJI has been openly committed to the promotion of the employability of its students, providing a high level of responsibility in the transition from college to work. In the section of the strategic plan of the UJI [3] that involves students, objective 21 refers to: "(..) promoting the labour insertion of the students." In addition, other objectives of the strategic document of the university are related to this aim (consolidating educational model [4]; recognizing effort and talented student) Taking into account the new EEES scene, it is still more important considering the needs of our students and graduates in order to improve their opportunities of professional career and their training to work in a changing environment.

The office for Career Development and Workplacements (Career Service, CS) is responsible to the

Vice-rectorate for Students Employment and Educational Innovation. Its aim is to introduce added value to the students' educational experience in order to increase their opportunities and prepare them to work in an international environment. It is the main instrument for putting into practice policies concerning students' employability. [5] Since 1998, workplacements have been managed through a 
single service (CS), and since 2002 the powers of this service have been increasing. Moreover, since 2010 the CS is an independent office and it is intended to promote employability and to enhance the career opportunities of graduates and students through different initiatives. The main programmes developed are: international workplacements for students (Erasmus + Placements Programme, University Junior International Entrepreneurs; and Poor Countries Solidarity Placements), Professional Guidance, Employability training (SuperTuesday for the Employment; Careers Events) Intermediary actions (as Job Vacancies;) Conferences and Job Fairs ("Ocuparty" Programme) and the Career Observatory. Every programme has a year's follow-up and assessment of results. Also, a process of ISO 9001 Quality Standards is being introduced for the core process. We are aware of our responsibilities towards our clients and have a service chart in which our commitments and success indicators are published: [6] All programmes are coordinated. We also encourage every trainee on a placement to participate in career guidance activities. Since its origins, Universitat Jaume I was pioneer in Spain in the promotion of workplacements in order to develop future employability, and it adopted a model of obligatory placements in which $100 \%$ of its graduated students had at least one professional experience.

\subsection{Benchmarking}

In this context, we have carried out diferent bechmarking studies through direct contact with good practices in other universities. Especially the revised reference has been the international context, in British universities that we have visited and with which we have had direct contact:

In many Universities in the United Kingdom there is the "graduates attributes model" [8] system, which is similar to the educational model, but it highlights the competences that must be achieved by the students. A definition will be "A policy statement created by a HE provider to inform academic development. These statements detail the qualities and skills that the provider believes graduates should develop through the course of their study and engagement in student life. Graduate attributes are defined differently from one HE provider to another but generally include components which relate to the mastery of subject-specific knowledge, study skills, digital literacies and other 21st century skills."

University of Kent [9] "Employability Points Squeme": through participation in activities, published each year, which have two principles 1) relevance to employability 2) commitment to compliance; which facilitate them to obtain assessed points, students have access to "points awards" such as participation in internships; projects and work experience.

Collected activities: presentations at conferences; organize events at the University; part-time job; go through employment service, conduct interviews; Mentoring, student awards, volunteering; studying, working or volunteering abroad (extra-academic); complete language courses; training in skills ...

University of Glasgow: [10] "HEAR project": Support to the student in the elaboration and monitoring of an electronic portfolio through Mahara, to equip them with a certificate of recognition in all workshops related to the employability that they organize (The students do not receive academic credits). In their web they relate the competences to develop, and behaviors and evidences that are suggestions to the students on how to increase these competences. An officer in charge of this website and coordinating with the academics. They are starting to use the Mahara for this. They have one booklet for students and one for academics. Students decide the privacy level of their portfolio: 1 , private; 2 university, 3 web. In addition, PhD Students are working in transversal skills workshops.

The Hear project is wider, since it includes recognition for actions of employability, representation, sports, internships and employment, volunteering, associationism. Also it is published a guide for academic staff.

\section{METHODOLOGY}

The objective of the system is to visualize and demonstrate to the potential employers the acquisition of transversal skills of the students with high impact on employability, through participation in training, awareness and experience activities organized by the Universitat Jaume and/or others that may be recognized by the evaluating committee (Committee of Experts).

This recognition will be independent of the recognition of skills for entrepreneurship [11] [12] and accreditation in foreign languages, that are set up with a similar process. 
In the next paragraph we will go in depth with the procedure, approved by the Management Committee of the University, which includes Rector and all the Vice-rectors of Universitat Jaume I.

\section{RESULTS}

\subsection{Procedure for the System of employability skills recognition}

The outcome is the recognition and validation (for undergraduates and recent graduates in the last two academic years in Bachelor/Master/PhD) of 700 hours of activities in training, increasing awareness and experience actions.

The process will be completed with the issue of a formal document duly signed by the Secretary of the University.

\subsection{Public call}

The applications will be submitted by the telematic register of the Universitat Jaume I and will be directed to the Career Development and Workplacements (Career Service, CS). For this purpose, an administrative procedure will be created within the catalog of administrative procedures of the Universitat Jaume I. Together with the application for recognition of competences for employability, documents must be attached that confirm that the requirements established in each call are fulfilled.

The documentation will be reviewed and validated by a committee of experts, which will study the individual application of each student / graduate. The committee of experts will be formed by:

Table 1. Composition of the Committee of Experts.

\begin{tabular}{l|c}
\hline \hline Presidency & Members \\
\hline Secretary & $\begin{array}{c}\text { Vicerectorate for Students, Employment and Educational Innovation } \\
\text { Vicerectorate for Studies }\end{array}$ \\
\hline Chairs & Three members of the Employability Board (Academic Staff, Companies) \\
& Students political representative \\
\hline \hline
\end{tabular}

The committee will meet at least once a year at the proposal of the presidency and its function will be to evaluate the requests and issue a reasoned resolution.

\subsection{Requirements for the recognition}

The applicant must have carried out training, awareness and experience actions, during or after their degree that are specified below:

Table 2. Requirements for the System of recognition of Employability Skills.

\begin{tabular}{l|l|l|l}
\hline \hline & Training & Increasing awareness & Experience Actions \\
\hline Total amount & At least 80 hours & At least 20 hours & At least 600 hours or 6 months \\
\hline
\end{tabular}


Table 3. Activities included in the recognition system.

\begin{tabular}{|c|c|c|}
\hline & Definition & Activities \\
\hline Training & $\begin{array}{l}\text { In soft skills, through programmes } \\
\text { organised or recognised by UJI } \\
\text { (organisations with powers in } \\
\text { employability: Higher education } \\
\text { Institutions, Public Service of } \\
\text { employment or other entities) }\end{array}$ & $\begin{array}{l}\text { - Careers Days } \\
\text { - } \text { "SuperTuesday for the Employabity" (short } \\
\text { workshops) } \\
\text { - Training programme for International placements } \\
\text { (set of specific workshops) } \\
\text { - Vocational guidance } \\
\text { - Job Conferences/Days recognised by Committee of } \\
\text { Experts }\end{array}$ \\
\hline $\begin{array}{l}\text { Increasing } \\
\text { awareness }\end{array}$ & Attendance to this kind of events & $\begin{array}{l}\text { - "Ocuparty" (Company presentation and recruitment } \\
\text { events) } \\
\text { - Job Fairs/Networking/Professional workshops } \\
\text { recognised by Committee of Experts }\end{array}$ \\
\hline $\begin{array}{l}\text { Experience } \\
\text { actions }\end{array}$ & $\begin{array}{l}\text { One experience or the sum of } \\
\text { different experiences }\end{array}$ & $\begin{array}{l}\text { - } \quad \text { Final dissertation Bachelor/Master in a company } \\
\text { - } \quad \text { Extracurricular placements } \\
\text { - } \quad \text { International Placement Programmes (Leonardo, } \\
\text { Erasmus Placements, Erasmus + Placements, } \\
\text { Solidarity Placements in Poor Countries, University } \\
\text { Junior International Entrepreneurs, Stella Junior, and } \\
\text { so forth) } \\
\text { - } \quad \text { Mobility programmes organised by UJI (Erasmus +, } \\
\text { Asia, North America, Latin America, SICUE } \\
\text { programme, and so forth) } \\
\text { - } \quad \text { Fellowship/assistantship (which their skills are related } \\
\text { with the student's degree) } \\
\text { - } \text { Research fellowship } \\
\text { - Voluntary programmes } \\
\text { Mentoring programmes }\end{array}$ \\
\hline
\end{tabular}

\section{CONCLUSIONS}

It will be delivered to the graduate or undergraduate a final certification by the Universitat Jaume I.

This system of recognition of employability skills will be launched in early 2018 , starting by the open process for students and graduates. The next steps to run cost-effectively the process are:

The communication of the benefits of this process to all stakeholders, by different methods (website, social media, workshops and meetings) including:

- Educational community, including professors and administrative staff,

- Potential employers, including public and private,

- Graduates and undergraduates.

- Other higher education institutions, both national and international,

- Scientific and dissemination journals related to the topic,

- Also families and the society in general.

\section{REFERENCES}

[1] Cedefop (2014). Terminology of European education and training policy: a selection of 130 terms. 2nd ed. Luxembourg: Publications Office. 
[2] Williams,S.; Dodd, L.; Steele, C. and Randall, R. "A systematic review of current understandings of employability" Journal of Education and Work, 2016. Volume. 29, No. 8, pp 877-901, 2016,

[3] Universitat Jaume I, strategic plan: Retrieved from http://www.uji.es/institucional/estrategia/plans/estrategic/

[4] Educational Model of the Universitat Jaume Retrieved from http://ujiapps.uji.es/institucional/estrategia/plans/modeleducatiu/

[5] Lapeña Barrachina, L. and Beas, M. I. "The role of the Careers Service Area of the UJI in enhancing the employability of students and recent graduates". International Techonology Education and Development Conference INTED. Internacional. Científic. 2007. Ed. International Academy of Technology, Education and Development (IATED).

[6] OIPEP, Service charter. Retreived from http://www.uji.es/serveis/oipep/base/carta/

[7] Graduate attributes framework: Retreived from https://www.heacademy.ac.uk/knowledgehub/graduate-attributes-framework

[8] University of Kent: Employability points Retreived from www.kent.ac.uk/

[9] University of Glasgow: HEAR project Retreived from https://www.gla.ac.uk/myglasgow/students/attributes/hearandyourdegree/

[10] Educational Model of the Universitat Jaume Retrieved from http://ujiapps.uji.es/institucional/estrategia/plans/modeleducatiu/

[11] UJI Emprèn: Retreived from http://ujiapps.uji.es/perfils/empresa/ujiempren/

[12] García-Agustín, P. Beas-Collado, M. I. and Ripollés, M. "UJI Emprèn: How to enhance entrepreneurship from the university side?" 9th International Technology, Education and Development Conference Pages: 7070-7078 Published: 2015. 